\title{
Covid-19 Pandemi Sürecinin Muhasebe Meslek Elemanları Üzerindeki Etkisi: Yalova Örneği*
}

\author{
The Impact of the Covid-19 Pandemic on Accounting Professionals: The Case of Yalova
}

\author{
Nuraydın Topcu*1(D) Vedat Demirkol ${ }^{1}$ (D)
}

${ }^{1}$ Department of Business Administration, Yalova University, Yalova, Turkey

\begin{abstract}
Received: 07.07.2021
Accepted: 27.09.2021

This article was checked by intihal.net

Öz

Covid-19 pandemi süresince insanların en önemli kaygısı kendi sağlıkları ve güvenlikleri olmuştur. Covid-19 salgını ekonomik, politik ve sosyal alanların çoğunu etkilemiş, işletmeler de bu yeni duruma uyum için bazı tedbirler almak zorunda kalmışlardır. Birçok işletme iş süreçlerini değiştirerek uzaktan çalışmak zorunda kalmıştır. Muhasebe mesleği de bu yeni duruma uyum sağlamak zorunda kalmıştır. Bu çalışmanın amacı, Yalova Serbest Muhasebeci ve Mali Müşavirler Odası (Yalova SMMMO) üyesi muhasebe meslek mensuplarının ve stajyer mali müşavirlerin Covid-19 salgınından nasıl etkilendiğini araştırmaktır. Bu kapsamda, bu muhasebe meslek mensuplarına bir anket uygulanmıştır. Covid-19 öncesi ve Covid-19 sürecinde karşılaşmış oldukları değişkenler arasında herhangi bir farklılık olup olmadığı tespit edilmeye çalışılmıştır. Yapılan analizlere göre, muhasebe meslek mensuplarının Covid-19 öncesine göre çalışma saatinde ve iş yükü seviyesinde bir farklılık tespit edilmemiştir. Ancak gelirlerinde, alacakların tahsilinde, iş yükünde, iletişim ve iş stresi seviyesinde, uzaktan çalışma sıklı̆ında Covid-19 öncesine göre anlamlı farklılığın olduğu görülmektedir. Ayrıca katılımcıların \%89,8'i bu süreçte herhangi muhasebe paket programını satın almadıklarını ifade etmişlerdir.
\end{abstract}

Anahtar Kelimeler: Pandemi, Covid-19, Uzaktan Çalışma, Muhasebe Mesleği

\section{Abstract}

During the Covid-19 pandemic, people's top concerns have been their health and safety. The Covid-19 pandemic has affected most of the economic, political, and social fields. Companies have had to adapt to this new situation. Many companies have had to work remotely by changing their business processes. The accounting profession also has to adjust to this unique situation. This study aims to investigate how the members of the Yalova Chamber of Certified Public Accountants and CPA trainees are affected by the Covid-19 pandemic. In this context, a questionnaire was applied to these accounting professionals. This study aims to determine the difference between the professional variables that professional accountants encountered before and during the Covid-19 period. The research results showed that the Covid-19 pandemic significantly affected the activity of accounting professionals in Yalova. According to the analysis, this study found no significant difference in professional accountants' working hours and workload compared to the pre-Covid-19 period. However, there is a significant difference in their income, collection of receivables rate, workload, communication, and work stress level, remote working-level compared to the pre-Covid-19 period. In addition, $89,8 \%$ of the participants stated that they did not purchase any accounting software program during the Covid-19 pandemic.

Keywords: Pandemic, Covid-19, Remote Working, Accounting Profession

Topcu, N. \& Demirkol, V. (2021). Covid-19 Pandemi Sürecinin Muhasebe Meslek Elemanları Üzerindeki Etkisi: Yalova Örneği. Journal of Academic Value Studies, 7(3), 344-353. http://dx.doi.org/10.29228/javs.52026

\footnotetext{
* Bu çalışma, 9-11 Haziran 2021 tarihleri arasında, Kırgızistan-Türkiye Manas Üniversitesi ev sahipliğinde düzenlenen 2. Uluslararası İktisadi ve İdari Bilimler Kongresi'nde sözlü bildiri olarak sunulmuştur.

${ }^{* *}$ E-mail address: nuraydin.topcu@yalova.edu.tr (Corresponding author)
} 


\section{Giriş}

2019 sonlarında Çin'in Wuhan şehrinde bir sağlık krizi olarak ortaya çıkan Covid-19 pandemisi, daha sonraki süreçte ekonomik ve sosyal hayatı büyük ölçüde etkilemiştir. Covid-19 salgını döneminde insanların en önemli kaygısı kendisi ve çevresindeki insanların sağlıkları olmuştur. Bu sebeple pandemi tedbirleri kapsamında işletmeler kapatılmış veya üretim seviyelerini azaltmış, işletmelerin karşılaştıkları belirsizlik ve riskler artmış, çalışanlar uzaktan çalışmak zorunda kalmışlar, işletmeler mal ve hizmetlerin tedarikinde, alacakların tahsilinde sorunlarla karşılaşmış, devletler işletmeler ve çalışanlar için bazı ekonomik destek programları açıklamak zorunda kalmışlardır. Bu yüzden Covid-19 pandemisinden, etkilenmeyen çalışan, işletme ve meslek kalmadığı ifade edilebilir. Muhasebe ve müşavirlik alanında çalışanlar genel sistem teorisi gereği genel ekonomik ekosistemin bir parçası ve ekosistem içerisinde devlet ve işletmeler arasında muhasebe ve müşavirlik hizmetleri vermelerinden dolayı, herkesi etkilediği gibi bu alanda çalışan kişiler de Covid-19 pandemisinden etkilenmiştir.

Ekonomik ve sosyal etkileriyle birlikte Türkiye'de binlerce meslek mensubu Covid-19'a yakalanmış ve yaklaşık 130 meslek mensubu hayatını kaybetmiştir (Akdemir, 2021). Araştırma kapsamında olan Yalova Serbest Muhasebeci ve Mali Müşavirler odasına bağlı 3 meslek mensubu Covid-19 pandemisinden kaynaklı olarak vefat etmiştir. Yalova ilinde 30 meslek mensubu ise bu süreçte Covid-19'a yakalanmıştır. Ayrıca meslek mensuplarının bu dönemde "pandemiye yakalanırım" veya "aile üyelerime bu virüsü bulaştırıım" gibi endişeler psikolojilerini bozmuş ve de kendilerini yıpratmıştır

Bu çalışmada, Yalova SMMMO üyesi muhasebe ve müşavirlik alanında çalışanların Covid-19 sürecinde karşılaştıkları sorunların Covid-19 öncesine göre karşılaştırma yapılacak, Covid-19 öncesine göre anlamlı bir farklı olup olmadığını, muhasebecilerin uzaktan çalışma ile ilgili yaklaşımlarını ele almayı amaçlamaktadır. Çalışmada, serbest muhasebeci ve mali müşavirler, serbest muhasebecileri ve stajyer muhasebecilerin Covid-19 sürecinde ve Covid-19 öncesine iç ve dış faktörler arasındaki ilişki tespit edilmeye çalışılmıştır.

\section{Literatür Araştırması}

Covid-19'un muhasebe meslek mensuplarının üzerindeki etkilerini ve sonuçları incelemeden önce kısaca muhasebe mesleğinin ne yaptığının, muhasebe meslek mensupların yaptıkları işin niteliği, muhasebe meslek mensuplarının mesleki faaliyetleri nasıl yaptıklarını, muhasebe meslek elemanlarının genelde karşılaştıkları sorunların ele alınması gereklidir. Bu çerçevede meslek mensuplarının faaliyette bulundukları iç ve dış faktörlerden kaynaklanan veya mesleklerini icra ederken karşılaştıkları sorunlar ilgili yapılan çalışmalar incelendiğinde meslek mensuplarının verdikleri hizmetlerin tahsilat sorunu (Biyan, 2012; Kalaycı ve Tekşen, 2006; Yıldırım ve Güney, 2012; Alagöz ve Ceran, 2007; Katkat Özçelik, 2018; Uzay ve Güngör, 2004), haksız rekabet (Biyan, 2012; Deran, vd., 2016, Uzay ve Güngör, 2004; Kalaycı ve Tekşen, 2006; Katkat Özçelik, 2018), iş yükü veya seviyesi (Alagöz ve Ceran, 2007; Deran vd., 2016; Kalaycı ve Tekşen, 2006; Katkat Özçelik, 2018; Arıkan, 2006; Uzay ve Güngör, 2004), yapılan işe bağlı olarak alınan ücretin düşük olması (Deran vd., 2016; Uzay ve Güngör, 2004; Yıldırım ve Güney, 2012), mevzuattın sürekli değişmesi (Alagöz ve Ceran, 2007; Deran vd., 2016, Uzay ve Güngör, 2004, Kalaycı ve Tekşen, 2006; Yıldırım ve Güney, 2012; Katkat Özçelik, 2018), muhasebecilerin sorumluluğunun fazla olması (Uzay ve Güngör, 2004; Hacıhasanoğlu ve Karaca, 2014) ve mesleki saygınlı̆̆ının olması (Biyan, 2012) ile ilgili mesleki sorunlar araştııılmıştır.

Araştırma verilerinin elde edilmesinde birincil veri elde etme yöntemi olan anket tekniği kullanılmıştır. Anket sorularının hazırlanmasında öncelikle muhasebe meslek mensuplarının en çok karşılaştıkları yukarıda ifade edilen sorunlar ile ilgili literatür taranarak bu alanda yapılmış olan araştırmalardan (Alagöz ve Ceran, 2007; Deran vd., 2016; Kalaycı ve Tekşen, 2006; Katkat Özçelik, 2018; Arıkan, 2006; Uzay ve Güngör, 2004; Alagöz ve Ceran, 2007; Deran vd., 2016; Kalaycı ve Tekşen, 2006; Katkat Özçelik, 2018; Arıkan, 2006; Uzay ve Güngör, 2004) ve (Papadopoulou ve Papadopoulou, 2020) yararlanılarak anket soruları hazırlanmıştır. Bu çalışmada ise muhasebe meslek mensuplarının Covid-19 öncesi karşılaştıkları bu sorunlarla Covid-19 esnasında karşılaştıkları bu sorunların seviyesi arasında herhangi bir anlamlı farkııı̆ın olup olmadığı tespit edilmeye çalışımıştır.

Durumsallık Yaklaşımı, Genel Sistem ve Kurumsallık Teorisine göre işletmeler içinde bulundukları iç ve dış koşullarına uyum sağlamaya ve koşulların gerekliliği olan tedbirleri almak zorundadırlar. Öncelikle muhasebe meslek mensuplarının Covid-19 sürecine yaklaşımları veya tepkileri sahip oldukları iç ve dış çevrenin koşullarına göre değişmiştir. Bu kapsamda Albitar ve diğerleri (2020), Covid-19'un sosyal mesafesinin denetim ücretlerini, işletme değerlendirmesini, insan sermayesini denetlemeyi, denetim prosedürlerini, denetim personeli maaşlarını ve denetim çabasını ve sonuçta denetim kalitesini etkileyebileceğine inanmaktalar. Muhasebe meslek çalışanlarının etkilenmesine yönelik yapılan 
çalışmalarda, işletmelerin muhasebe meslek mensuplarının iş yoğunluğu, gelir kaybı personel istihdam edilme yönetimi, devlet desteği veya mesleki birliklerin destekleri, uzaktan çalışma, Covid-19 süresince müşterilerle iletişim, alacakların tahsil edilmesi sorunu gibi değişkenlerle Covid-19 öncesi ve sonrasına yönelik yaptıkları araştırmada anlamlı farklılık tespit etmişlerdir (Papadopoulou ve Papadopoulou, 2020). Ayrıca Covid-19'dan kaynaklanan fiziksel kısıtlamalar ve ekonomik zorluklar, muhasebecilerin üretkenliğini, işlerini gerçekleştirme becerilerini, müşteriler ve iş arkadaşlarıyla ilişkileri sürdürme becerilerini ve gelecekteki hizmetleri potansiyel müşterilere satma becerisini de engellemiştir (Heltzer ve Mindak, 2021).

Şu ana kadar muhasebe alanında Covid-19 ile ilgili çok az çalışma yapılmıştır. Muhasebe alanında yapılan çalışmalar genel de Covid-19 süreciyle beraber ortaya çıkan ekonomik belirsizliklerin ve risklerin muhasebeleştirmeye ve finansal raporlamaya olan etkisi (Demir, 2020; Özdemir, vd., 2020) ve denetçilerin Covid-19 sürecinde veri elde etmede yaşadıkları sorunlar ve işletmelerin karşılaştıkları belirsizliklerin işletmelerin sürekliliğine, bağımsız denetimin planlanmasına, kanıt elde edilmesine ve raporlanmasın bağımsız denetime olan etkisi incelenmiştir (Karakaya, 2020; Köse ve Ağdeniz, 2020; Adana ve Özbirecikli, 2020). Ayrıca Covid-19 tedbirleri kapsamında eğitim kurumları kapanması sebebiyle muhasebe eğitimi uzaktan yapılmak zorunda kalınmıştır. Bu çerçevede Covid-19 süresince muhasebe alanında değerlendirme, performans ölçümü vb. konular ile ilgili çalışmalar yapılmıştır (Serçemeli ve Kurnaz, 2020; Sangster vd., 2020:432) ve ayrıca Covid-19 süresince muhasebe meslek mensuplarının iş yoğunluğu, gelir kaybı, muhasebe meslek elemanlarına (Papadopoulou ve Papadopoulou, 2020) ve iş stresi (Kardeş Selimoğlu vd., 2021), mesleki tükenmişlik (Buyruk Akbaba ve Bulut, 2021) olan etkisiyle ilgili çalışmalar yapılmıştır.

\section{Araştırmanın Amacı}

Bu çalışmanın amacı, Yalova ilinde faaliyet gösteren muhasebe meslek mensuplarının mesleki faaliyetlerinde Covid-19 öncesi ve Covid-19 sürecinde karşılaşmış oldukları mesleki sorunlar arasında herhangi bir farklılık olup olmadığı tespit edilmeye çalışılmıştır.

\section{Araştırmanın Yöntemi ve Sınırlııkları}

Bu çalışmanın ana kütlesi, Yalova Serbest Muhasebeci ve Mali Müşavirleri odası üyesi muhasebe ve müşavirlik mesleğini filli olarak icra eden 187 meslek mensubundan ve Yalova SMMMO üyesi meslek mensuplarının yanında çalışan stajyer mali müşavir adaylarından oluşmaktadır. Araştırmanın anket formu Google Documentation uygulaması üzerinden hazırlanarak, 2021 yılııın Nisan ve Mayıs aylarında internet üzerinden araştırma kapsamında olan meslek mensuplarına gönderilmiştir. Gönderilen anketlerden 59 geri dönüş olmuştur. Toplam anakütlenin bir kısmının muhasebe mesleğini de aktif olarak yerine getirmediği düşünüldüğünde Toplam ana kütlenin yaklaşık \%30'undan geri dönüş olduğu görülmektedir.

Araştırmanın anket formu iki bölümden oluşmaktadır. Birinci bölümde ankete katılan muhasebe meslek mensuplarının cinsiyeti, mesleki unvanı, eğitim düzeyi, çalışma şekli, mesleki deneyimi, pandemi döneminde muhasebe paket programı satın alıp almadıkları, pandemi öncesi ve sürecinde mesleki gelir tutarı, pandemi öncesi ve sürecinde mesleki çalışma süresi gibi sorulara yer verilmiştir. İkinci bölümde ise, pandemi öncesi ve sürecinde muhasebe meslek mensuplarının iş yoğunluğu, muhasebe ve meslek ücretlerinin tahsil seviyesi, iş yükü, iş stresi, müşterilerle iletişim, uzaktan çalışma seviyesine ilişkin sorulara yer verilmiştir. Bu bölümdeki sorular $5^{\prime}$ li likert ölçeğine göre düzenlenmiştir. "Çok Düşük", "Düşük", "Orta”, "Yüksek", "Çok Yüksek" ve "Hiçbir Zaman"," Nadiren”, "Ara Sıra", "Genellikle", "Her Zaman" seçenekleriyle ölçek hazırlanmıştır. Bu ölçeklerin Cronbach Alpha güvenirlik katsayısı 0,751 olarak hesaplanmıştır.

Araştırmada rastgele örneklem seçimiyle anket formunu cevaplayacak kişiler seçilmiştir. Anket verileri IBM SPSS 26 paket programı ile analiz edilmiştir. Elde edilen verilerin analizinde güvenirlilik, normallik testi, frekans dağıımları, non parametrik testlerden Wilcoxon, Mann Whitney $U$ ve parametrik T-testi gibi istatistiki analizler yapılmış ve Tablo $1^{\prime}$ 'de yer alan hipotezler test edilmiştir. 


\section{Tablo 1. Araştırmanın Hipotezleri}

\begin{tabular}{|l|}
\hline H1: Covid-19 öncesi ve esnası gelir seviyesi arasında anlamlı farklıık yoktur. \\
\hline H2: Covid-19 öncesi ve esnası mesleki tahsilat sorunu seviyesi arasında anlamlı farklıık yoktur. \\
\hline H3: Covid-19 öncesi ve esnası iş yükü seviyesi arasında anlamlı farkııık yoktur. \\
\hline H4: Covid-19 öncesi ve esnası iş stresi seviyesi arasında anlamlı farklıık yoktur. \\
\hline H5: Covid-19 döneminde muhasebe uygulama ve paket programı alımı yapılmamıştır. \\
\hline H6: Covid-19 öncesi ve esnası uzaktan çalışma seviyesi arasında anlamlı farklıık yoktur. \\
\hline H7: Covid-19 öncesi ve sonrası uzaktan çalışma seviyesi arasında anlamlı farklılık yoktur. \\
\hline H8: Covid-19 dönemi ve sonrası uzaktan çalışma süresi arasında anlamlı farklılık yoktur. \\
\hline H9: Covid-19 öncesi ve esnası mükelleflerle iletişim seviyesi arasında anlamlı farklıık yoktur. \\
\hline
\end{tabular}

\section{Bulgular}

Çalışmanın bu bölümde anket sonucunda elde edilen bulgular tartışılmıştır. Bu kapsamda öncelikle frekans dağılımları sunulmuş ve hipotezler test edilmiştir. Buna göre Tablo 2'ye göre, ankete katılanların yaklaşı \% 54,2 'si kadın ve \%45,8'ide erkeklerden oluşmaktadır. Çoğunluğu 50 yaş altı olan kişilerden (\%78), \%22'side 51 yaşın üzerindedir. Ayrıca, ankete katılanların büyük bir kısmı lisans derecesine sahip $(\% 62,7)$ ve serbest muhasebesi ve mali müşavir $(\% 71,2)$ olarak çalışmaktadırlar. Çalışmaya katılanların \%66,1'i büro sahibi ve ortağı olan kişilerden oluşmaktadır.

\section{Tablo 2. Frekans Dağılımları}

\begin{tabular}{|c|c|c|}
\hline & Frekans & Yüzde (\%) \\
\hline \multicolumn{3}{|l|}{ Cinsiyet } \\
\hline Erkek & 27 & 45,8 \\
\hline Kadın & 32 & 54,2 \\
\hline \multicolumn{3}{|l|}{ Yaşınız } \\
\hline 30 ve altı & 6 & 10,2 \\
\hline $31-40$ & 23 & 39,0 \\
\hline $41-50$ & 17 & 28,8 \\
\hline 51 ve üstü & 13 & 22,0 \\
\hline \multicolumn{3}{|l|}{ Öğrenim Seviyesi } \\
\hline Orta Öğretim & 4 & 6,8 \\
\hline Ön lisans & 3 & 5,1 \\
\hline Lisans & 37 & 62,7 \\
\hline Lisansüstü & 15 & 25,4 \\
\hline \multicolumn{3}{|l|}{ Mesleki Unvan } \\
\hline SMMM Stajyeri & 7 & 11,9 \\
\hline Serbest Muhasebeci & 3 & 5,1 \\
\hline SMMM & 42 & 71,2 \\
\hline SMMM-Bağımsız Denetçi & 7 & 11,9 \\
\hline Çalışma Şekli & & \\
\hline
\end{tabular}




\begin{tabular}{|c|c|c|}
\hline Büro Sahibi/Ortağı & 39 & 66,1 \\
\hline İ̧ Akdi ile Çalışmaktayım & 20 & 33,9 \\
\hline Mesleki Deneyim & & \\
\hline 5 ve altı & 11 & 18,6 \\
\hline $6-10$ & 10 & 16,9 \\
\hline $11-15$ & 8 & 13,6 \\
\hline $16-20$ & 9 & 15,3 \\
\hline 21 ve üstü & 21 & 35,6 \\
\hline Toplam Gözlem Sayısı & 59 & \\
\hline
\end{tabular}

\subsection{Covid-19 Sürecinde Gelir Kaybı}

Muhasebe meslek elemanlarının esas geliri, muhasebe ve müşavirlik alanında hizmet verdikleri kişilerden ve kurumlardan elde ettikleri gelirlerden oluşmaktadır. Covid-19 sürecinde işletmelerin tamamen veya kısmen kapanması veyahut bazı işletmelerin faaliyetlerini sonlandırması ya da ekonomik durgunluk sonucunda çoğu sektörde işletmelerin gelirlerinde veya kârlarında önemli düşüşler olmuştur. İşletmelere muhasebe ve müşavirlik alanında hizmet veren kişileri de etkilemiştir. Bu durum ise muhasebe ve müşavirlik alanında çalışan kişilerin gelirlerinin azalmasına yol açmıştır. Ayrıca muhasebe meslek elemanlarının mesleki ücreti tahsil etme sorunları daha da artmıştır. Tablo 3'te yer alan Paired Samples T testi sonucuna göre Covid-19 öncesi sırasına göre muhasebe meslek mensuplarının gelirlerinin seviyesinde anlamlı bir farklılık olduğu görülmektedir $(\mathrm{p}=0,00<0,05)$. Bu kapsamda "H1: Covid-19 öncesi ve esnası gelir seviyesi arasında anlamlı farkılılk yoktur." reddedilmiştir. Meslek mensuplarının Covid-19 öncesine göre Covid-19 öncesine gelirlerinde önemli düşüş olduğu görülmektedir.

\section{Tablo 3. Gelir Kaybı}

\begin{tabular}{|c|c|c|c|c|c|c|c|}
\hline & $n$ & $\bar{x}$ & $\begin{array}{l}\text { Standart } \\
\text { Sapma }\end{array}$ & $\begin{array}{c}\text { Standart } \\
\text { Hata }\end{array}$ & $\mathrm{Sd}$ & $\mathrm{t}$ & $p$ \\
\hline $\begin{array}{c}\text { Covid-19 ÖNCESI ortalama } \\
\text { aylık geliriniz. }\end{array}$ & 59 & 3,0678 & 1,50705 & 19620 & \multirow[t]{2}{*}{58} & \multirow[t]{2}{*}{5,204} & \multirow[t]{2}{*}{,000 } \\
\hline $\begin{array}{c}\text { Covid-19 SIRASINDA ortalama } \\
\text { aylık geliriniz. }\end{array}$ & 59 & 2,4068 & 1,19075 & 15502 & & & \\
\hline $\begin{array}{c}\text { Covid-19'dan ÖNCE } \\
\text { muhasebe ve müşavirlik } \\
\text { ücretlerinin tahsil sorunu. }\end{array}$ & 59 & 3,2203 & ,85234 & 11096 & \multirow[t]{2}{*}{58} & \multirow[t]{2}{*}{$-2,068$} & \multirow[t]{2}{*}{,043 } \\
\hline $\begin{array}{l}\text { Covid-19 SIRASINDA } \\
\text { muhasebe ve müşavirlik } \\
\text { ücretlerinin tahsil sorunu. }\end{array}$ & 59 & 3,5254 & 1,34364 & 17493 & & & \\
\hline
\end{tabular}

Tablo 3'ye yer alan Paired Samples T testi sonucuna göre, anlamlıık seviyesi $(p=0,043<0,05)$ olduğundan dolayı "H2: Covid-19 öncesi ve esnası mesleki tahsilat sorunu seviyesi arasında anlamlı farklılık yoktur." hipotezi reddedilmiştir. Covid-19 öncesine göre muhasebe ve müşavirlik ücretlerin seviyesinde anlamlı bir farklılığının olduğu görülmektedir. Bu kapsamda anketin açık uçlu bölümünden elde edilen cevaplara göre cevap veren katılımcılar mükelleflerin mesleki ücretleri erteledikleri ve çok düşük düzeyde ödeme yaptıklarını ifade etmişlerdir. Anketlerden elde edilen veriler analiz edildiğinde Covid-19 öncesi ve Covid-19 sürecinde muhasebe meslek elemanlarının elde ettikleri gelir karşılaştııılı̆̆ında muhasebe meslek elemanlarının gelirlerinde azalma olduğunu bazı mükelleflerin bu dönemde ücret verme konusunda istekli olmadıkları veya meslek mensuplarının düzenli muhasebe ücretlerinin tahsilinde sorunlar yaşadıkları görülmektedir. 


\subsection{Covid-19 Sürecinde İş Yükü ve Günlük Çalışma Süresi}

Mali müşavirlerin ve muhasebe meslek mensuplarının başlıca sorunları arasında angaryalar ve gelişen teknolojiyle azalması beklenen ama hep artan iş yükü olarak görülebilir (Ulusoy, 2020). Daha önce yapılan araştırmalardan anlaşılacağı üzere, muhasebe meslek elemanları genelde en çok dile getirdiği konuların ve karşılaştıkları sorunların başında iş yükü gelmektedir (Alagöz ve Ceran, 2007; Deran vd., 2016; Kalaycı ve Tekşen, 2006; Katkat Özçelik, 2018; Arıkan, 2006; Uzay ve Güngör, 2004). İ̧ yükü yoğunluğu kavramı, çalışana işyerinde yüklenen işin normalin üzerinde olduğuna yönelik genel algıdır (Keser, 2006:105). Diğer bir ifade ile zaman baskısı (sıkı teslim tarihleri, mesai ve hafta sonu çalışma), yüksek çalışma hızı ve iş yükü miktarının yüksek olması (aşırı iş yükü) gibi çalışma talebinin birçok boyutunu kapsayan bir kavramdır (Skinner ve Pocock, 2008:306). Muhasebe mesleğinde iş yoğunluğunu ekonomik gelişmeler, yasal düzenlemeler ve işletmelerin talepleri gibi nedenlerle artmaktadır. Bu kapsamda Covid-19 pandemi sürecinde kamu kurumlarının bazı vergisel bildirimleri veya beyannameleri (KDV, Muhtasar, Ba-Bs formları) ertelemesine rağmen kısa çalışma ödeneği, nakit ücret desteği, ücretsiz izinlerin sisteme girilmesi vb. işletme sahipleri veya yöneticileri tarafından yapılması gereken işlemlerin muhasebe meslek mensupları tarafından yapıldığını da ifade etmişlerdir. Bu kapsamda Tablo 4'te yer alan iş hacmi analiz ve yapılan Paired Samples Test sonuçlarına göre, anlamlılık seviyesi $(p=0,139>0,05)$ olduğundan dolayı, Covid-19 öncesi ve Covid-19 esnasında iş hacmi seviyesi arasında herhangi anlamlı bir fark tespit edilmemiştir. Böylece "H3: Covid-19 öncesi ve esnası iş yükü seviyesi arasında anlamlı farklılık yoktur." Hipotezi kabul edilmiştir. Yani Covid-19 sürecinde Yalova SMMMO üyesi meslek mensuplarının iş yükünde önemli derecede azalma meydana getirmemiştir

Tablo 4. İ̧ Hacmi Analiz Sonuçları

\begin{tabular}{|c|c|c|c|c|c|c|c|}
\hline & $\bar{x}$ & $\mathrm{~N}$ & $\begin{array}{l}\text { Standart } \\
\text { Sapma }\end{array}$ & $\begin{array}{l}\text { Standart } \\
\text { Hata }\end{array}$ & $s d$ & $\mathrm{t}$ & $p$ \\
\hline Covid-19 ÖNCESi iş hacmi seviyesi. & 3,1186 & 59 & ,81123 & 10561 & \multirow[t]{2}{*}{58} & \multirow[t]{2}{*}{$-1,499$} & \multirow[t]{2}{*}{139} \\
\hline Covid-19 SIRASINDA iş hacmi seviyesi. & 3,3051 & 59 & 1,14853 & 14953 & & & \\
\hline
\end{tabular}

Benzer bir şekilde Covid-19 ve Covid-19 sırasındaki çalışılan günlük çalışma süresi ile ilgili analiz yapıldığında, öncelikle verilerin normal dağılım gösterip göstermedikleri analiz edilmiştir. Yapılan analiz de Covid-19 öncesiyle ve Covid-19 süreciyle ilgili günlük çalışma verilerinin normal dağılım göstermedikleri tespit edilmiştir. Bu sebeple, NonParametric Testlerden Wilcoxon Testi uygulanmıştır. Tablo 5'te yer alan analiz sonuçlarına göre, Covid-19 öncesi ve sırasındaki çalışma saati süresinin anlamlılık seviyesi $(0,957>0,05)$ olduğundan dolayı "H8: Covid-19 dönemi ve sonrası uzaktan çalışma süresi arasında anlamlı farklıık yoktur." hipotezi kabul edilmiştir. Yani muhasebe meslek mensupları Covid-19 öncesi ve pandemi esnasında mesleklerine aynı mesai ayırmışlardır. Kamu kurumlarının bu dönemde getirdikleri bazı yeni uygulamaları meslek mensuplarının çalışma sürelerinin aynı seviyede kalmasını sağlamıştır.

Tablo 5. Günlük Çalışma Analiz Sonuçları

\begin{tabular}{|l|rr|}
\hline & $\begin{array}{c}\text { Covid-19 SIRASINDA günlük çalışma saatiniz. - Covid-19 ÖNCESi günlük } \\
\text { ortalama çalışma saatiniz. }\end{array}$ \\
\hline Z & &,$- 053^{\mathrm{b}}$ \\
\hline Asymp. Sig. (2-tailed) & 957 \\
\hline a. Wilcoxon Signed Ranks Test & \\
\hline b. Based on positive ranks. & \\
\hline
\end{tabular}


Tablo 6. Günlük Çalışma Ortalaması

\begin{tabular}{|c|c|c|c|c|}
\hline \multicolumn{2}{|c|}{} & N & Mean Rank & Sum of Ranks \\
\hline Covid-19 SIRASINDA & Negative Ranks & $14^{\mathrm{a}}$ & 12,68 & 177,50 \\
\cline { 2 - 5 } günlük çalışma saatiniz. - & Positive Ranks & $12^{\mathrm{b}}$ & 14,46 & 173,50 \\
\cline { 2 - 5 } $\begin{array}{c}\text { Covid-19 ÖNCESi günlük } \\
\text { ortalama çalışma saatiniz. }\end{array}$ & Ties & $33^{\mathrm{c}}$ & & \\
\cline { 2 - 5 } & Total & 59 & & \\
\hline a. Covid-19 SIRASINDA günlük çalışma saatiniz. < Covid-19 ÖNCESi günlük ortalama çalışma saatiniz. \\
\hline b. Covid-19 SIRASINDA günlük çalışma saatiniz. > Covid-19 ÖNCESi günlük ortalama çalışma saatiniz. \\
\hline c. Covid-19 SIRASINDA günlük çalışma saatiniz. = Covid-19 ÖNCESi günlük ortalama çalışma saatiniz. \\
\hline
\end{tabular}

\subsection{Covid-19 Sürecinde İş Stresi}

İ̧ stresi, çalışanın ve iç/dış çevresi arasında olan etkileşim sonucunda ortaya çıkan gerilim olarak ifade edilebilir (Efeoğlu ve Özgen, 2007:239). Bu kapsamda Covid-19 süreciyle birlikte her meslek grubunda olduğu gibi muhasebe meslek mensuplarının da en önemli endişesi kendi ve çevresindeki insanların sağlıkları olmuştur. Yine meslek mensuplarının bu dönemde Covid-19'a yakalanma endişesi veya işin tam zamanında yetiştirilmeme, yasal ceza yaptırım korkusu, iş yükü ve maddi sıkıntılar insanlar üzerinde stres oluşturmuş bu durum da iş stresine neden olduğunu ifade edebiliriz.

Tablo 6'da yer alan ve araştırmadan elde edilen veriler incelendiğinde, anlamlılık seviyesi $(p=0,00<0,05)$ olduğundan dolayı Covid-19 yapılan Covid-19 öncesi ve sırası arasında anlamlı bir ilişki olduğu görülmektedir. Bu kapsamda "H4: Covid-19 öncesi ve esnası iş stresi seviyesi arasında anlamlı farklılık yoktur." Hipotezi reddedilmiştir. Covid-19 sürecindeki iş stresinin Covid-19 öncesine göre anlamlı bir farklılık olduğu görülmektedir. Ayrıca anketin açık uçlu sorular bölümünde katılımcılar, bu dönemde Covid-19'a yakalanma korkusu, artan iş yükü (nakit ücret desteği ve kısa çalışma ödeneği gibi mükelleflerin düzenlemeleri gereken bazı işlemlerin/evrakların kendilerinin hazırlamaları), personel eksikliği, devletin ve odaların yetersiz destekleri gibi nedenler iş stresini artırdığını da ifade etmişlerdir.

Tablo 6. İş Stresinin Analiz Sonuçları

\begin{tabular}{|c|c|c|c|c|c|c|c|}
\hline & $\bar{X}$ & $\mathrm{~N}$ & $\begin{array}{c}\text { Standart } \\
\text { Sapma }\end{array}$ & $\begin{array}{c}\text { Standart } \\
\text { Hata }\end{array}$ & $\mathrm{sd}$ & $\mathrm{t}$ & $\mathrm{p}$ \\
\hline $\begin{array}{c}\text { Covid-19'dan ÖNCE işle } \\
\text { ilgili stres seviyesi. }\end{array}$ & 3,4068 & 59 &, 94902 &, 12355 & 58 & $-6,338$ &, 000 \\
\cline { 1 - 5 } $\begin{array}{c}\text { Covid-19 SIRASINDA } \\
\text { işle ilgili stres seviyesi. }\end{array}$ & 4,0678 & 59 &, 98023 &, 12761 & & \\
\hline
\end{tabular}

\subsection{Covid-19 Sürecinde Muhasebe ve Teknoloji Kullanımı}

Araştırmaya katılan meslek mensuplarının \%89,8,'i bu dönemde herhangi bir muhasebe uygulamasını veya programını satın almadığını ifade ederken, katılımcıların \%10,2'si de muhasebe uygulamasını veya paket programını satın aldığını ifade etmiştir. Bu sonuç Covid-19 pandemi öncesinde muhasebe mesleğinde yoğun bir teknoloji yatırımı bulunduğu ve muhasebe mesleğinde yoğun olarak teknoloji kullanıldığını göstermektedir. Bu durum Covid-19 sürecinde muhasebe meslek mensuplarının işini kolaylaştırmış ve muhasebe mesleğinin uzaktan çalışmaya en uygun mesleklerden biri olduğunu göstermiştir. 
Tablo 7. Muhasebe Programı veya Uygulaması Satın Alma Frekans Sonuçları

Covid-19 pandemisi esnasında herhangi bir muhasebe programı veya uygulamasını satın aldınız mı?

\begin{tabular}{|c|c|c|}
\hline & Frequency & Percent \\
\hline Evet & 6 & 10,2 \\
\hline Hayır & 53 & 89,8 \\
\hline Total & 59 & 100,0 \\
\hline
\end{tabular}

\subsection{Covid-19 Sürecinde Uzaktan Çalışma}

Covid-19 süreciyle beraber çok sayıda meslekte uzaktan çalışma konusu gündeme gelmiştir. Çalışanların uzaktan çalışabilmesi için öncelikle yapılan işin uzaktan yapılmaya uygun olması ve işletmenin uzaktan çalışmayı yürütebileceği teknik alt yapıya sahip olması gereklidir. Bu kapsamda muhasebe mesleği uzaktan çalışmaya en uygun mesleklerden biri olduğunu ifade edebiliriz. Çünkü muhasebe mesleğinin her alanında yoğun olarak teknoloji kullanılmaktadır. Uzaktan çalışma ile ilgili analiz sonuçların yer aldığı Tablo 8'e göre, her bir uzaktan eğitim ile ilgili hipotezin anlamlıık seviyesi $(p=0,00<0,05)$ olduğundan dolayı $\mathrm{H6}, \mathrm{H7}$ ve $\mathrm{H} 8$ hipotezleri reddedilmiştir. İşletmelerin muhasebe meslek mensuplarının Covid-19 öncesi, Covid-19 esnasında ve Covid-19 sonrasındaki uzaktan çalışma yapıları arasında anlamlı bir farklılığın olduğu görülmektedir.

Tablo 8. Uzaktan Çalışma Analiz Sonuçları

\begin{tabular}{|c|c|c|c|c|c|c|c|}
\hline & $\bar{X}$ & $\mathrm{~N}$ & $\begin{array}{c}\text { Standart } \\
\text { Sapma }\end{array}$ & Standart Hata & $\mathrm{Sd}$ & $\mathrm{t}$ & $p$ \\
\hline $\begin{array}{l}\text { Covid-19 salgınından ÖNCE } \\
\text { uzaktan çalıştınız mı? }\end{array}$ & 1,7458 & 59 & 77889, & 10140, & \multirow[t]{2}{*}{58} & \multirow[t]{2}{*}{$-7,300$} & \multirow[t]{2}{*}{,000 } \\
\hline $\begin{array}{l}\text { Covid-19 salgını SIRASINDA } \\
\text { uzaktan çalıştınız mı? }\end{array}$ & 2,7119 & 59 & 1,20417 & 15677, & & & \\
\hline $\begin{array}{l}\text { Covid-19 salgınından ÖNCE } \\
\text { uzaktan çalıştınız mı? }\end{array}$ & 1,7458 & 59 & 77889 & 10140, & \multirow[t]{2}{*}{58} & \multirow[t]{2}{*}{$-2,699$} & \multirow[t]{2}{*}{,009 } \\
\hline $\begin{array}{l}\text { Covid-19 SONRASI } \\
\text { (normalleşme döneminde) } \\
\text { uzaktan çalışmayı } \\
\text { düşünüyor musunuz? }\end{array}$ & 2,1017 & 59 & 1,01191 & 13174, & & & \\
\hline $\begin{array}{l}\text { Covid-19 salgını SIRASINDA } \\
\text { uzaktan çalıştınız mı? }\end{array}$ & 2,7119 & 59 & 1,20417 & 15677, & \multirow{2}{*}{58} & \multirow{2}{*}{4,685} & \multirow{2}{*}{,000 } \\
\hline $\begin{array}{l}\text { Covid-19 SONRASI } \\
\text { (normalleşme döneminde) } \\
\text { uzaktan çalışmayı } \\
\text { düşünüyor musunuz? }\end{array}$ & 2,1017 & 59 & 1,01191 & 13174 & & & \\
\hline
\end{tabular}

\subsection{Covid-19 Sürecinde Müşterilerle Illetişim}

Meslek mensupları mesleki faaliyetlerini sürdürebilmesi için öncelikle meslek mensuplarının ve çalışanlarının sağlıklarının koruyabilmesi ve olası bulaş riski seviyesini düşebilmesine bağlıdır. Bunun için yetkili kurumlar tarafından yayımlanan tedbir rehberlerine uymaları ve müşterilerle teması en alt seviyeye indirmeleri gereklidir. Covid-19 sürecinde pandemi tedbirleri kapsamında çok sayıda işletme kişiler arası iletişimi sınırlandırmış ya da teknolojik araçlarla müşterileriyle iletişimi sürdürmeye çalışmıştır. 
Tablo 9. Covid-19 sürecinde Müşterilerle İletişim

\begin{tabular}{|l|c|c|c|c|c|c|c|}
\hline & $\overline{\mathrm{X}}$ & $\mathrm{N}$ & $\begin{array}{c}\text { Standart } \\
\text { Sapma }\end{array}$ & $\begin{array}{c}\text { Standart } \\
\text { Hata }\end{array}$ & $\mathrm{sd}$ & $\mathrm{t}$ & $\mathrm{p}$ \\
\hline $\begin{array}{l}\text { Covid-19'dan ÖNCE } \\
\text { müşterilerle iletişim. }\end{array}$ & 3,6441 & 59 &, 88596 &, 11534 & 58 & 3,496 &, 001 \\
\hline $\begin{array}{l}\text { Covid-19 SIRASINDA } \\
\text { müşterilerle iletişim. }\end{array}$ & 3,1864 & 59 & 1,10601 &, 14399 & & \\
\hline
\end{tabular}

Tablo 9'da yer alan analiz sonuçlarına göre, bu hipotezin anlamlılık seviyesi $(p=0,00<0,05)$ olduğundan dolayı, Covid-19 öncesine göre müşterilerle iletişim seviyesine Covid-19 öncesine göre anlamlı bir farklılı̆ın olduğu görülmektedir. Bu kapsamda "H9: Covid-19 öncesi ve esnası mükelleflerle iletişim seviyesi arasında anlamlı farklılk yoktur." hipotezi reddedilmiştir. Yani Covid-19 öncesine göre muhasebe meslek mensuplarının Covid-19 sürecinde Covid-19 pandemi tedbirleri kapsamında, hizmet verdikleri işletmelerle iletişimlerini sınıllandırdıklarını ifade edebiliriz.

\section{Sonuç}

Covid-19 işletmeleri ve bireyleri sosyal ve ekonomik olarak etkilemiştir. Bu dönemde daha fazla uzaktan çalışma gündeme gelmiştir. Bu çalışmada, Yalova ilinde faaliyet gösteren muhasebe meslek mensuplarının Covid-19 salgınından nasıl etkilendiğini araştııımıştır. Yapılan bu çalışma da muhasebe meslek elemanlarının Covid-19 öncesi döneme göre, gelirlerinde, çalışma saatlerinde, iş stresinde, teknolojik yatırım ve uzaktan eğitim öncesine göre durumlarıyla karşılaştırma yapılmaya çalışılmıştır. Covid-19 döneminde işletmelerin tam veya kısmi kapanması sebebiyle muhasebe meslek mensuplarının Covid-19 öncesine göre gelirlerinde anlamlı bir farklılık tespit edilmiştir. Ayrıca muhasebe meslek mensuplarının en çok yakındıkları konulardan biri olan mesleki ücretlerin tahsili seviyesinde artı̧̧ olmuştur. Devletin bazı vergisel bildirimleri ertelemesine rağmen, kısa çalışma ödeneği ve nakit ücret desteği gibi bazı yeni bildirimleri muhasebe meslek mensuplarının yapması sebebiyle çalışma saatinde Covid-19 öncesine göre herhangi anlamlı farklıık tespit edilememiştir. Ancak muhasebe meslek mensuplarının iş yükünde, iş stresinde ve müşterilerle iletişimde Covid-19 öncesine göre anlamlı farklılığın olduğu görülmektedir. Ayrıca çalışma da elde edilen diğer bir bulgu da katılımcıların $\% 89,8^{\prime} i$ bu süreçte herhangi muhasebe paket programını satın almadıkları tespit edilmiştir. Mesleki gelirlerin önemli oranda azaldığı ve uzaktan çalışma sıklığının önemli oranda artığı bu dönemde, muhasebe meslek mensuplarının daha önce teknolojiye yaptıkları yatırımların önemi daha da iyi anlaşılıştır. Bu durum muhasebe meslek mensupları açısından olumlu bir gelişme olarak görülebilir. Muhasebe meslek elemanların Covid-19 esnasında ve sürecinde uzaktan çalışma sıklı̆̆ı arasında anlamlı bir farklılık tespit edilmiş̧ir. Bu kapsamda pandemi sürecinde kazanılan bazı alışkanlıkların pandemi sonrasında da devam edeceğini öngörülebilir. Meslek mensuplarının pandemi sürecinin çalışma yapısını uzaktan çalışma açısından etkileyeceğini ortaya koymaktadır.

\section{Kaynakça}

Adana, B. A. \& Özbirecikli M. (2020). Bağımsız Denetim Sürecinin Covid-19 Salgınının Etkileri Açısından Değerlendirilmesi. İ̧letme Araştırmaları Dergisi, 12(2), 2080-2093.

Akdemir, Y. (2021), Başkanla Mesleki Gündem 3, Erişim Tarihi: 10.05.202, https://www.youtube.com/watch?v=dOYVskAWOUo,

Alagöz, A. \& Ceran, Y. (2007). Muhasebe Meslek Mensuplarının Sorunları, Meslek Örgütünden Beklentileri ile Mesleki Vizyon Algılarını Belirlemeye Yönelik Bir Araştırma: Konya İli Uygulaması. Selçuk Üniversitesi İktisadi ve İdari Bilimler Fakültesi, Sosyal ve Ekonomik Araştırmalar Dergisi, 7(14), 291-312.

Albitar, K., Gerged, A.M., Kikhia, H. \& Hussainey, K. (2020). Auditing in times of social distancing: the effect of Covid-19 on auditing quality. International Journal of Accounting \& Information Management, 29(1),169-178.

Arıkan, Y. (2006). Muhasebe Meslek Mensuplarının Vergi Uygulamalarındaki Sorunlarına İlişkin Çözüm Önerilerimiz. Mali Çözüm, 75, 13-19.

Biyan, Ö. (2012). Muhasebe Meslek Mensuplarına Yönelik Bir Çalışma: Meslek Mensuplarının Demografik Durumları, Mesleki Sorunları ve Değerlendirilmesi. Sosyo Ekonomi Dergisi, 17 (17), 106-134. 
Buyruk Akbaba, A. N. \& Bulut, N. (2021). Pandemi Sürecinde Muhasebe Meslek Mensuplarının Mesleki Tükenmişlik Düzeylerinin Incelenmesi, European Journal of Managerial Research, 5(1), 35-48.

Deran, A., Erdurdu, i. \& Keleş, D. (2016). Muhasebe Meslek Mensuplarının Mesleki Sorunları ve Meslek Odalarından Beklentilerinin Demografik Özellikler ve Faaliyet Gösterilen Ekonomik Çevre Açısından Değerlendirilmesi: Ordu Örneği. Selçuk Üniversitesi iïBF Sosyal Ekonomik Araştırmalar Dergisi, 16(32), 84-109.

Efeoğlu, i. \& Özgen, H. (2007). İş-Aile Yaşam Çatışmasının İ̧̧ Stresi, İ̧̧ Doyumu ve Örgütsel Bağılık Üzerindeki Etkileri: Ilaç Sektöründe Bir Araştırma. Ç.Ü. Sosyal Bilimler Enstitüsü Dergisi, 16 (2), 237-254.

Hacıhasanoğlu, T. \& Karaca, N. (2014). Bağımsız Çalışan Muhasebe Meslek Mensuplarının ve Muhasebe Çalışanlarının Tükenmişlik, İ̧̧ Tatmini ve Stres Düzeylerinin Belirlenmesine Yönelik Bir Alan Araştırması. Süleyman Demirel Üniversitesi İktisadi ve İdari Bilimler Fakültesi Dergisi, (19)4,153-170.

Heltzer, W. \& Mindak, M. (2021). Covid-19 and the Accounting Profession. Journal of Accounting, Ethics and Public Policy 22(2), 151-205.

Kalaycı, Ş. \& Tekşen, Ö. (2006). Muhasebe Mesleğinde Karşılaşılan Sorunlar ve Çözüm Önerileri: Isparta il Merkezi Uygulaması. Muhasebe ve Finansman Dergisi, 31, 90-101.

Karakaya, G., (2020). COVID- 19 Gündeminde İşletme Sürekliliği ve Bağımsız Denetim Iliş̧kisi. İstanbul Ticaret Üniversitesi Sosyal Bilimler Dergisi, Bahar (Covid19-Özel Ek), 14-29.

Katkat Özçelik, M. (2018). Serbest Muhasebeci Mali Müşavirlerin Sorunları ve Bu Sorunların Cinsiyet Boyutu: Artvin ve Rize Örnekleri. Karadeniz Araştırmaları XV/58, 99-125.

Keser, A. (2006). Çağrı Merkezi Çalışanlarında İ̧̧ Yükü Düzeyi ile İ̧̧ Doyumu iliş̧isinin Araştırılması. Kocaeli Üniversitesi Sosyal Bilimler Enstitüsü Dergisi, 11, 100-119.

Köse, T. \& Ağdeniz, Ş. (2020). Covid-19 Salgınının BDS 570 İşletmenin Sürekliliği Standardının Uygulama Sürecine Etkileri. Mali Cözüm Dergisi, 30(161), 69-94.

Papadopoulou, S. \& Papadopoulou, M. (2020). The Accounting Profession Amidst the Covid-19 Pandemic. International Journal of Accounting and Financial Reporting. 10(2),2162-3082.

Sangster, A. G. S. \& Flood B. (2020). Insights into accounting education in a Covid-19 world. Accounting Education, 29(5), 431-562.

Skinner, N. \& Pocock, B. (2008). Work-life conflict: Is work time or work overload more important?. Asia Pacific Journal of Human Resources, 46(3), 303-315.

Kardeş Selimoğlu, S., Cengiz, A., Özdemir, A. \& Yalı, B. (2021). Covid-19 ile Birlikte Muhasebe Mesleğindeki Stresin Yeni Halleri. Muhasebe ve Denetime Bakış, 21(63), 1-18.

Serçemeli, M. \& Kurnaz, E. (2020). Covid-19 Pandemi Döneminde Öğrencilerin Uzaktan Eğitim ve Uzaktan Muhasebe Eğitimine Yönelik Bakış Açıları Üzerine Bir Araştırma. Uluslararası Sosyal Bilimler Akademik Araştırmalar Dergisi, 4(1), 40-53.

Uzay, ş. \& Güngör, ş. (2004). Muhasebecilerin Sorunları ve Beklentileri: Kayseri ve Nevşehir illeri Uygulaması. Muhasebe ve Finansman Dergisi, 22, 94-104.

Ulusoy, A. (2020). Yenisafak, Mali Müşavirlerin Sorunları. Erişim Tarihi:24/05/2021, https://www.yenisafak.com/yazarlar/ahmet-ulusoy/mali-musavirlerin-sorunlari-ve-beklentileri-2-2055561.

Yıldırım, S. \& Güney, S. (2012). Serbest Muhasebeci Mali Müşavirlerin Genel Sorunları: Erzurum İli Örneği. Muhasebe ve Denetime Bakış Dergisi, 36, 35-48. 